\title{
Determination of growth kinetics and size dependent structural, morphological, optical characteristics of sol-gel derived silica nanoparticles in silica matrix
}

\author{
BENGÜ ÖZUĞUR UYSAL ${ }^{1,2 *}$, FATMA Z. TEPEHAN ${ }^{2}$ \\ ${ }^{1}$ Kadir Has University, Faculty of Engineering and Natural Sciences, Cibali, Fatih, Istanbul 34083, Turkey \\ ${ }^{2}$ Istanbul Technical University, Department of Physics Engineering, Faculty of Science and Letters, Maslak, Istanbul, Turkey

\begin{abstract}
Nanocomposite silica thin films made using the sol-gel method were studied. The nano-silica films were prepared using a mixture of tetraethyl orthosilicate (TEOS), deionized water, ethanol, and ammonia solution. To control the growth of the particles inside the film, the nanocomposite silica film was prepared using a mixture of the nano-silica sol and the silica sol. The change in the particle size with the heat treatment temperature ranging from $450{ }^{\circ} \mathrm{C}$ to $1100{ }^{\circ} \mathrm{C}$ was investigated. X-ray diffraction (XRD), atomic force microscopy (AFM), scanning electron microscopy (SEM), NKD (refractive index-N, extinction coefficient-K, and thickness-D) and ultraviolet-visible (UV-Vis) spectrophotometry were used for characterization purposes. The XRD studies showed that the nano-silica thin films were amorphous at all annealing temperatures except for $1100{ }^{\circ} \mathrm{C}$. The $\alpha$-cristobalite crystal structure formed at the annealing temperature of $1100{ }^{\circ} \mathrm{C}$. Optical parameters, such as refractive indices and extinction coefficients, were obtained using the NKD analyzer with respect to the annealing temperature of the films. The activation energy and enthalpy of the nanocomposite silica film were evaluated as $22.3 \mathrm{~kJ} / \mathrm{mol}$ and $14.7 \mathrm{~kJ} / \mathrm{mol}$, respectively. The cut-off wavelength values were calculated by means of extrapolation of the absorbance spectra estimated using the UV-Vis spectroscopy measurements. A red shift in the absorption threshold of the nanocomposite silica films indicated that the size of the silica nanoparticles increased with an increase of the annealing temperatures from $450{ }^{\circ} \mathrm{C}$ to $900{ }^{\circ} \mathrm{C}$, and this confirms the quantum confinement effect in the nanoparticles.
\end{abstract}

Keywords: particle size; silicon dioxide; sol-gel method; nanoparticled composite thin films

\section{Introduction}

Metal oxides as crucial functional materials are used in various fields of nanotechnology due to their physical properties. Silicon dioxide (silica, $\mathrm{SiO}_{2}$ ) is particularly preferred in the production of thin film substrates [1], electrical and thermal insulators [2], optical filters [3], solar cells and collector applications [4] because of its wide band gap, amorphous film structure and low refractive index [5]. Silica-based nanocomposites $\left(\mathrm{SiO}_{2}-\mathrm{P}_{2} \mathrm{O}_{5}\right.$ [6], $\mathrm{Er}^{+}$-doped $\mathrm{SiO}_{2}-\mathrm{TiO}_{2}$ [7], $\mathrm{SiO}_{2}-\mathrm{TiO}_{2}$ [8, 9], $\mathrm{ZnO}-\mathrm{SiO}_{2}$ [10]) are used in many research studies in order to control the shape, size and other properties of nanostructured films [11, 12]. The sol-gel technique is the most common process used to synthesize silica

*E-mail: bozugur@khas.edu.tr particles, where the particle size depends on the sol-gel chemistry. The Stöber process [13] has also been used to synthesize colloidal silica nanoparticles. Effect of concentration of chemicals (i.e. TEOS, ethanol, methanol, ammonia solution, $\mathrm{HCl}$, oxalic acid, $\mathrm{NaOH}, \mathrm{NH}_{4} \mathrm{~F}, \mathrm{H}_{2} \mathrm{O}$ ) and their ratios during both the hydrolysis and condensation reactions to control particle size have been discussed [ 2 , $6,14-20]$. Size-dependent optical properties of silica nanoparticles highlighting the change in physicochemical properties of silica at smaller particle sizes have been reported in several papers that display unique optical absorption characteristics [1928]. Optical measurements have been used to determine different parameters of silica based composite films of varying particle size which generate a quantum confinement effect [26, 29, 30].

Studies on silicon dioxide thin films have shown that $\mathrm{WO}_{3}-\mathrm{SiO}_{2}$ nanocomposite films [31], $\mathrm{SiO}_{2}$ 
and $\mathrm{TiO}_{2}$ multilayered optical filters [4], $\mathrm{Ta}_{2} \mathrm{O}_{5}$, $\mathrm{SiO}_{2}$ multilayered antireflective coatings [32], and Si-doped $\mathrm{ZnO}$ transparent thin films [33] can be synthesized using sol-gel technique. The effects of $\mathrm{NH}_{3}$ /TEOS ratios on the particle size of the $\mathrm{SiO}_{2}$ and nanostructured $\mathrm{SiO}_{2}$ films prepared by sol-gel spin coating technique were investigated in our previous work [34]. However, dependence of the optical properties (transmission, refractive index, extinction coefficient) of the silica nanoparticled composite films on particle size and temperature has not been studied intensively before. Therefore, in this study, sol-gel spin coated nanocomposite $\mathrm{SiO}_{2}$ films were produced from a mixture that had a proper ratio of $\mathrm{SiO}_{2}$ and nano- $\mathrm{SiO}_{2}$ sols, for a thorough investigation. The refractive index and the extinction coefficient of the nanocomposite $\mathrm{SiO}_{2}$ films were investigated by using the transmission data in $\mathrm{s}$ and $\mathrm{p}$-polarization modes with respect to the applied heat treatment for an annealing temperature range of $450{ }^{\circ} \mathrm{C}$ to $1100{ }^{\circ} \mathrm{C}$. The detailed studies on surface morphology of the nanocomposite films obtained at different annealing temperatures provided the size information of the particles contained in the films. Regarding the control of the particle size in nanostructured films, the solgel deposition process is the easiest and most commonly used technique. Supporting this assertion, this study indicates that the annealing temperature affects the particle size of nanocomposite $\mathrm{SiO}_{2}$ thin films and the new film structure prevents further growth of silica nanoparticles in the film resulting in useful physicochemical properties. In addition, the activation energy and enthalpy have been determined through the growth kinetics of the nanoparticles. To the best of our knowledge, this is the first study on calculation of activation enthalpy for silica nanoparticled films derived by sol-gel process.

\section{Experimental}

\subsection{Film preparation}

The $\mathrm{SiO}_{2}$ sol was made using a mixture of two solutions: the first solution was made with TEOS dissolved in ethanol. The second solution was obtained by mixing deionized (DI) water, ethanol $\left(0.789 \mathrm{~g} / \mathrm{mL}\right.$ at $\left.25^{\circ} \mathrm{C}\right)$ and hydrochloric acid $(\mathrm{HCl}$ $1.2 \mathrm{~g} / \mathrm{mL}$ at $\left.25^{\circ} \mathrm{C}\right)$. Then, the second solution was added to the first solution at room temperature, until the $\mathrm{SiO}_{2}$ solution became homogeneous and transparent as detailed in Fig. 1a. The nano- $\mathrm{SiO}_{2}$ sol was prepared with TEOS, deionized water and ethanol and catalyzed by ammonia (Fig. 1b). The mole ratio of ammonia/TEOS was 1:32 in the final solution.

The $\mathrm{SiO}_{2}$ and nano- $\mathrm{SiO}_{2}$ solutions were mixed at room temperature for $30 \mathrm{~min}$. at a volume ratio of 1:10 to obtain uniform suspension of silica nanoparticles in silica sol. Then, these solutions were spin coated on quartz glasses at $1000 \mathrm{rpm}$ for $30 \mathrm{~s}$. The coatings were heat treated at $450{ }^{\circ} \mathrm{C}$, $550{ }^{\circ} \mathrm{C}, 650{ }^{\circ} \mathrm{C}, 900{ }^{\circ} \mathrm{C}$ for $1 \mathrm{~h}$, to calculate the activation energy. In order to investigate the crystal phase, the final coatings were heat treated at $1100{ }^{\circ} \mathrm{C}$ for $48 \mathrm{~h}$ employing a microprocessorcontrolled (CWF 1100) furnace.

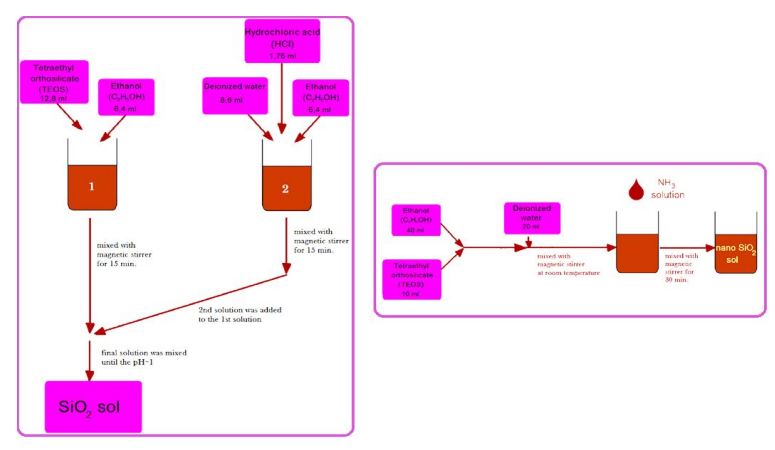

Fig. 1. Preparation scheme of $\mathrm{SiO}_{2}$ and nano- $\mathrm{SiO}_{2}$ sols.

\subsection{Characterizations}

The XRD patterns of the films were recorded with an X-ray diffractometer (GBC-MMA) using monochromatized $\mathrm{CuK} \alpha$ radiation $(\lambda=1.54056 \AA)$ with a scanning $2 \theta$ range of $20^{\circ}$ to $80^{\circ}$, and with a grazing angle of $1^{\circ}$. The International Center for Diffraction Data (ICDD) database was used for characterization of the coated thin films. The morphology of the films was examined using a scanning electron microscope (SEM, JSM-7000F, JEOL Ltd.) and scanning probe microscope (Model SPM-9500, Shimadzu Corp.) incorporating an atomic force 
microscope (AFM) in dynamic mode. Optical transmittance and absorbance values of the films were measured with a spectrophotometer (NKD 7000, Aquila Inst.) and UV-Vis spectrophotometer (Agilent 8453). Refractive indices and extinction coefficients were evaluated using the Pro-Optix software incorporated within the NKD analyzer. The thickness of the films was measured using a Stylus Profilometer (Veeco, Dektak 150).

\section{Results and discussion}

\subsection{XRD analysis}

The heat treatment temperatures were chosen at almost equal increments: $450{ }^{\circ} \mathrm{C}, 650{ }^{\circ} \mathrm{C}, 900{ }^{\circ} \mathrm{C}$ and $1100{ }^{\circ} \mathrm{C}$ for the nano- $\mathrm{SiO}_{2}$ thin films. The XRD analysis showed that the films were amorphous for the coatings heat treated at the temperatures of $450{ }^{\circ} \mathrm{C}, 650{ }^{\circ} \mathrm{C}$, and $900{ }^{\circ} \mathrm{C}$ (Fig. 2). No diffraction peak was observed but a broad band centered at $2 \theta=22.00^{\circ}$ appeared which is the characteristic behavior of amorphous $\mathrm{SiO}_{2}$ (JCPDS Card No. 29-0085). For the films heat treated at temperature of $1100{ }^{\circ} \mathrm{C}$ a very strong crystallization of $\alpha-\mathrm{SiO}_{2}(\alpha$-cristobalite phase) occurred for the nano-SiO $\mathrm{Silm}_{2}$ (JCPDS Card No. 00-001-0438). The $\alpha$-cristobalite structure was observed at $1100{ }^{\circ} \mathrm{C}$, as reported before by other groups $[35,36]$.

A slow XRD scan was used to calculate the average crystallite size $\mathrm{D}_{\text {cryst }}$ of the film, using Scherrer formula as follows:

$$
D_{\text {cryst }}=\frac{K \lambda}{B \cos \theta}
$$

where $\mathrm{K}$ is a constant (0.89), $\lambda$ is the wavelength of the incident radiation (for $\mathrm{Cu} \mathrm{K} \alpha$ radiation $\lambda=1.54056 \AA$ ), $\mathrm{B}$ is the full width at halfmaximum (FWHM) of the diffraction line and $\theta$ is the Bragg diffraction angle. The most intense diffractions of the $\alpha$-cristobalite phase were observed at $2 \theta=22.08^{\circ}$ and $36.10^{\circ}$, and the average nanocrystallite size of these diffraction peaks was found to be $18.6 \mathrm{~nm}$ for a nano- $\mathrm{SiO}_{2}$ thin film with a ratio of ammonia/TEOS $=1: 32$, heat treated at $1100{ }^{\circ} \mathrm{C}$ for $48 \mathrm{~h}$.

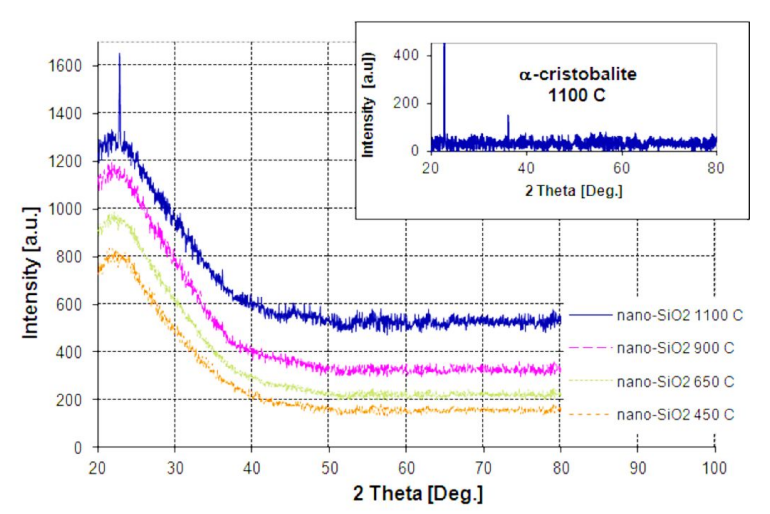

Fig. 2. XRD spectra of nano-SiO $\mathrm{S}_{2}$ films heat-treated at different annealing temperatures.

\subsection{Surface morphology of the films}

Fig. 3a displays the AFM image of the $\mathrm{SiO}_{2}$ film. The nano- $\mathrm{SiO}_{2}$ film with its granular structure is shown in Fig. 3b, and the observed particle size of this film is about $50 \mathrm{~nm}$. Fig. 4 shows that the annealing temperature of the nanoparticled composite silica films affects the size of the nanoparticles. The sizes of the silica nanoparticles, calculated using the SPM Manager Program, were found to be approximately $16 \mathrm{~nm}, 42 \mathrm{~nm}, 63 \mathrm{~nm}$, and $18 \mathrm{~nm}$ at different heat treatment temperatures of $450{ }^{\circ} \mathrm{C}, 650{ }^{\circ} \mathrm{C}, 900{ }^{\circ} \mathrm{C}$ and $1100^{\circ} \mathrm{C}$, respectively, as shown in Table 1. Particle size is inversely proportional to the number of particles per area. When the size of particles contained in a film is decreased, the particles display a more regular structure, and are aligned. In addition to these measurements, a coating heat-treated at $550{ }^{\circ} \mathrm{C}$ was measured giving an average silica nanoparticle size of $23 \mathrm{~nm}$. This value was used for the calculation of the activation energy.

The nanocomposite $\mathrm{SiO}_{2}$ film is formed by a nano- $\mathrm{SiO}_{2}$ structure consisting of spherical nanostructured $\mathrm{SiO}_{2}$ particles. The particle size of the nanocomposite $\mathrm{SiO}_{2}$ film, heat treated at $450{ }^{\circ} \mathrm{C}$, as shown in Fig. 4a, is relatively smaller compared to the nano- $\mathrm{SiO}_{2}$ film annealed at the same temperature as illustrated in Fig. 3b. In this way, it can be seen that the growth of the silica nanoparticles is prevented by the nanocomposite structure because of encapsulation of the nanoparticles in the silica gel matrix. 
Table 1. Profile analysis results of nanocomposite $\mathrm{SiO}_{2}$ film heat-treated at different annealing temperatures.

\begin{tabular}{cccc}
\hline $\begin{array}{c}\text { Annealing } \\
\text { temperature } \\
{\left[{ }^{\circ} \mathrm{C}\right]}\end{array}$ & $\begin{array}{c}\text { Maximum } \\
\text { particle diameter }[\mathrm{nm}]\end{array}$ & $\begin{array}{c}\text { Surface area } \\
{\left[\mathrm{nm}^{2}\right]}\end{array}$ & $\begin{array}{c}\text { Number of particles } \\
\text { per } 2.5 \times 2.5 \mu \mathrm{m}^{2}\end{array}$ \\
\hline \hline 450 & 16 & 50667 & 252 \\
650 & 42 & 91439 & 66 \\
900 & 63 & 121572 & 39 \\
1100 & 18 & 26973 & 106 \\
\hline
\end{tabular}
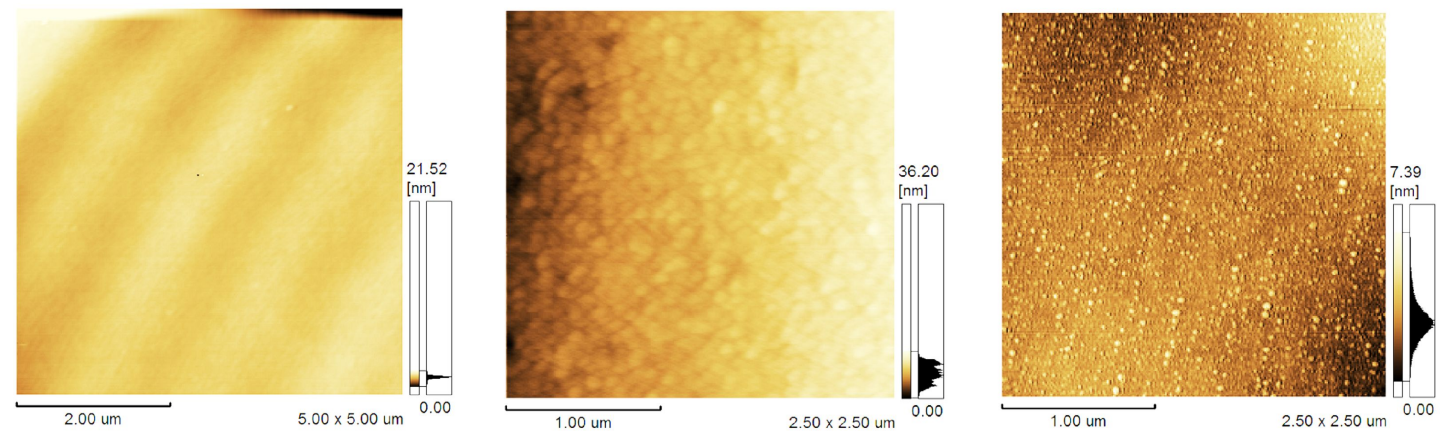

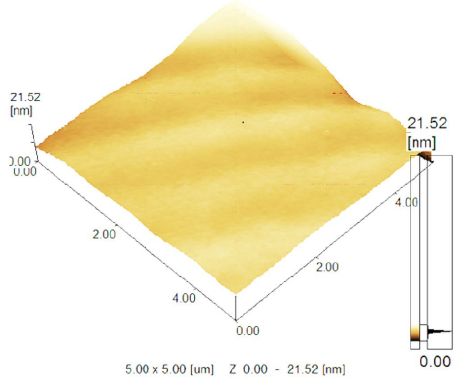

(a)

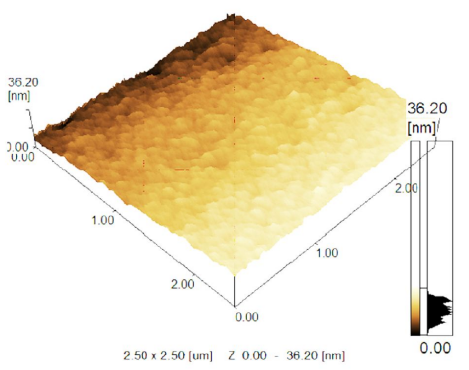

(b)

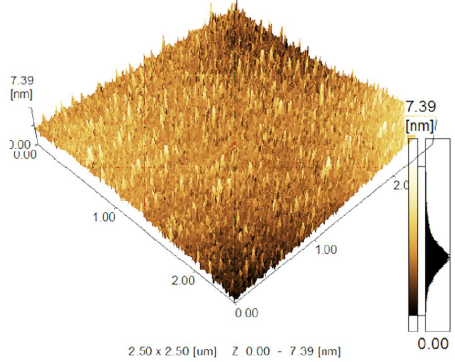

(c)

Fig. 3. $2 \mathrm{D}$ and 3D AFM images of (a) $\mathrm{SiO}_{2}$ film, (b) nano- $\mathrm{SiO}_{2}$ film, (c) nanocomposite $\mathrm{SiO}_{2}$ film.

The SEM image of the nanocomposite $\mathrm{SiO}_{2}$ film (ammonia/TEOS $=1: 32$ ) heat treated at temperature of $450{ }^{\circ} \mathrm{C}$ with an average particle size of $15 \mathrm{~nm}$, is shown in Fig. 5a. There are some agglomerations in the film, but the tubular-like alignment of the particles confirms the AFM results of the film as displayed in Fig. 4a. The SEM image of the nano- $\mathrm{SiO}_{2}$ film annealed at $1100{ }^{\circ} \mathrm{C}$ is shown in Fig. 5b. The average particle size of this film is observed to be about $20 \mathrm{~nm}$ in the SEM image, which is slightly greater than the value determined using the SPM Manager, as shown in Table 1. For the annealing temperature of $1100{ }^{\circ} \mathrm{C}$, the nano- $\mathrm{SiO}_{2}$ thin film has an $\alpha$-cristobalite phase as mentioned before and in the case of the transformation to the crystal phase, the size of the nanoparticles of the nano- $\mathrm{SiO}_{2}$ film increases with annealing temperature. The calculated crystallite and observed particle size values of the films are displayed in Table 2 to facilitate the comparison. Thickness of the films was measured as approximately $43 \mathrm{~nm}$.

\subsection{Grain-growth kinetics}

The grain growth depends on annealing temperature and time, which can be analyzed using the grain-growth kinetics equations $[37,38]$, i.e.:

$$
d^{n}-d_{0}^{n}=k \cdot t
$$


Table 2. Particle sizes [nm] of the nano- $\mathrm{SiO}_{2}$ and nanocomposite $\mathrm{SiO}_{2}$ films.

\begin{tabular}{ccccc}
\hline & \multicolumn{2}{c}{ nano-SiO ${ }_{2}$ film } & \multicolumn{2}{c}{ nanocomposite $\mathrm{SiO}_{2}$ film } \\
Annealing & \multicolumn{2}{c}{$\begin{array}{c}\text { Calculated by Scherrer } \\
\text { Calculated }\end{array}$} & $\begin{array}{c}\text { Observed } \\
\text { Observed }\end{array}$ & $\begin{array}{c}\text { Cbser } \\
\text { temperature }\left[{ }^{\circ} \mathrm{C}\right]\end{array}$ \\
\hline \hline 450 & - & 50 & 16 & 15 \\
1100 & 18.6 & 20 & 18 & - \\
\hline
\end{tabular}

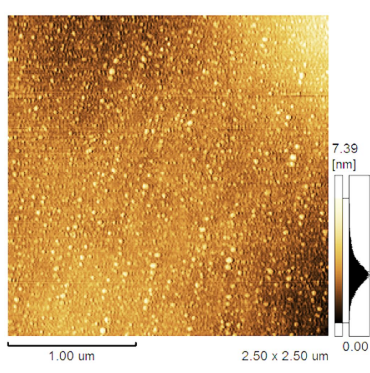

(a)

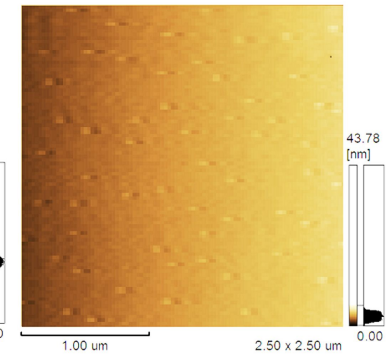

(b)

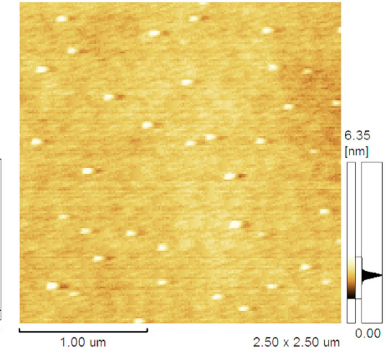

(c)

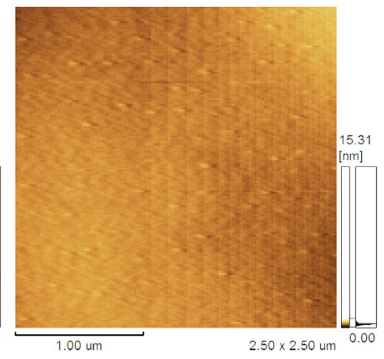

(d)

Fig. 4. AFM images of nanocomposite $\mathrm{SiO}_{2}$ film heat-treated at annealing temperatures of (a) $450{ }^{\circ} \mathrm{C}$, (b) $650{ }^{\circ} \mathrm{C}$, (c) $900{ }^{\circ} \mathrm{C}$, (d) $1100{ }^{\circ} \mathrm{C}$.

and:

$$
k=k_{0} \exp \left(\frac{-E_{a}}{R T}\right)
$$

where $\mathrm{d}$ is the average grain size at time $\mathrm{t}, \mathrm{d}_{0}$ is the average grain size at time $t=0, n$ is the growth exponent, $\mathrm{k}$ is a rate constant, $\mathrm{k}_{0}$ is a preexponential constant, $\mathrm{E}_{\mathrm{a}}$ is the activation energy of grain growth, $\mathrm{R}$ and $\mathrm{T}$ are the gas constant and absolute temperature. When $\mathrm{d}_{0}$ is significantly smaller than $\mathrm{d}, \mathrm{d}_{0}^{\mathrm{n}}$ can be neglected relative to $\mathrm{d}$, and the grain-growth kinetics equations can be simplified as follows [39]:

$$
\begin{gathered}
d=k_{0} \exp \left(\frac{-E_{a}}{R T}\right) t \\
\ln d=\frac{-E_{a}}{R T}+\ln k_{0}+\ln t
\end{gathered}
$$

The activation energy can be determined from the slope of the Arrhenius plot of $\ln (\mathrm{d})$ versus $1 / \mathrm{T}$. An alternative method for calculating the thermodynamic quantities of the system with the use of the rate constant $\mathrm{k}$ is the Eyring equation [40], which is expressed as:

$$
k=\left(\frac{k_{B} T}{h}\right) \exp \left[\frac{-\left(\Delta H^{*}-T \Delta S^{*}\right)}{R T}\right]
$$

where $\mathrm{k}_{\mathrm{B}}$ is Boltzmann constant, $\mathrm{h}$ is Planck constant, $\Delta \mathrm{H}^{*}$ and $\Delta \mathrm{S}^{*}$ are the activation enthalpy and entropy, and the average grain size can be expressed as:

$$
\begin{aligned}
d & =\left(\frac{k_{B} T}{h}\right) \exp \left[\frac{-\left(\Delta H^{*}-T \Delta S^{*}\right)}{R T}\right] t \\
\ln \left(\frac{d}{T}\right) & =f r a c-\left(\Delta H^{*}-T \Delta S^{*}\right) R T+\ln \left(\frac{k_{B}}{h}\right)+\ln t
\end{aligned}
$$

Fig. 6 shows the plot of $\ln (d)$ versus 1000/T for the nanocomposite $\mathrm{SiO}_{2}$ thin film. The slope yields the activation energy of $22.3 \mathrm{~kJ} / \mathrm{mol}$ which is much lower than the $E_{a}$ reported in the literature [41-44]. Because of the increase in total energy, nanoparticled thin films have a higher surface area. Thus, less energy is required to induce the particle growth of the nanostructured $\mathrm{SiO}_{2}$ films. Based on the Eyring equation, Fig. 7 shows the plot of $\ln (d / T)$ versus $1000 / T$ of the nanocomposite $\mathrm{SiO}_{2}$ thin film. The slope yields the activation 


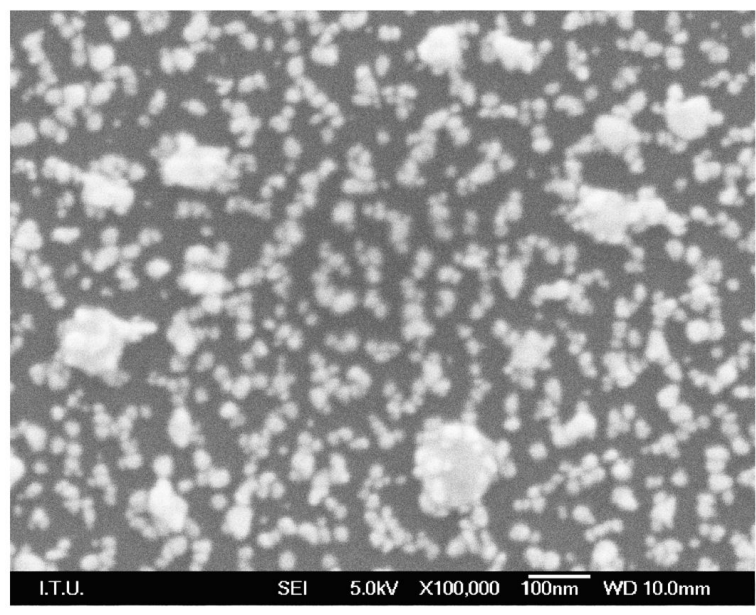

(a)

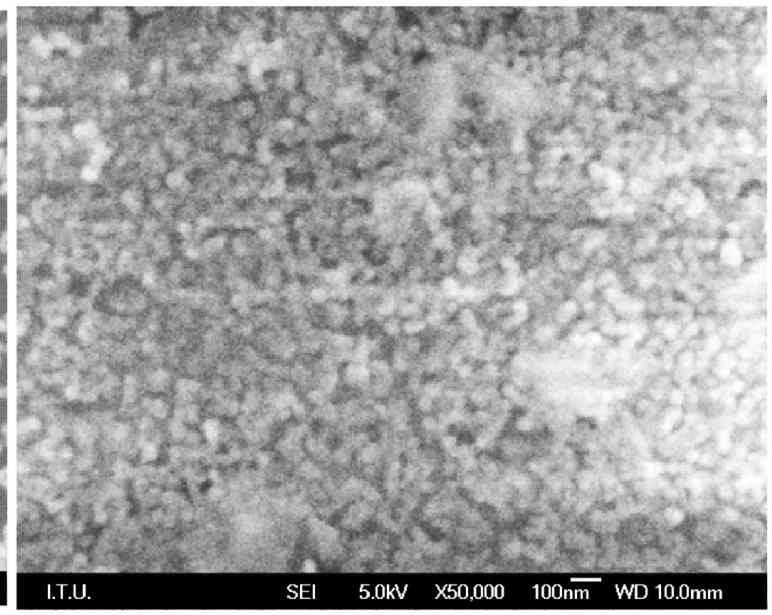

(b)

Fig. 5. FE-SEM images of (a) nanocomposite $\mathrm{SiO}_{2}$ film (ammonia/TEOS $=1: 32$ ) at the annealing temperature of $450{ }^{\circ} \mathrm{C}$, (b) nano-SiO 2 film (ammonia/TEOS $=1: 32$ ) at the annealing temperature of $1100{ }^{\circ} \mathrm{C}$.

enthalpy of $14.7 \mathrm{~kJ} / \mathrm{mol}$. A comparable study that determines the activation enthalpy of the nanoparticled composite films containing silica nanoparticles was not found. However, we encountered a study that found the global enthalpy for silica $(\alpha-$ cristobalite) dissolution in sodium hydroxide solution to be very close to our calculated activation enthalpy in absolute value [45]. An investigation of the relationship between the activation enthalpy and global enthalpy would be worth pursuing.

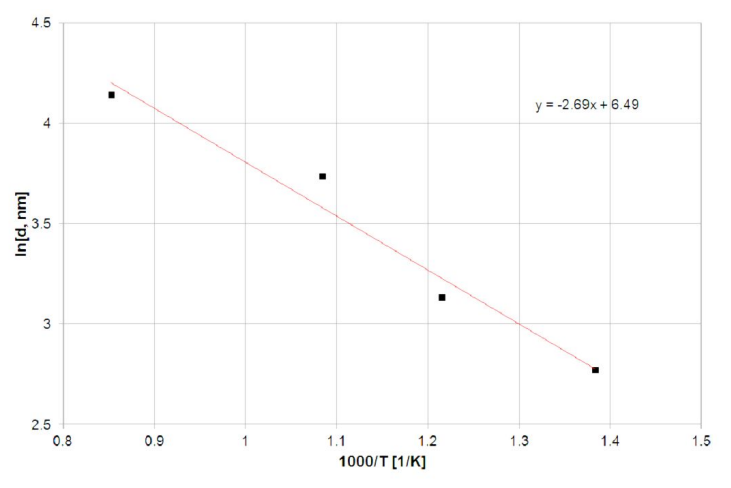

Fig. 6. Arrhenius plot of nanocomposite $\mathrm{SiO}_{2}$ film.

\subsection{Optical properties}

Fig. 8 and Fig. 9 present the transmittance spectra of the nanoparticled composite silica films

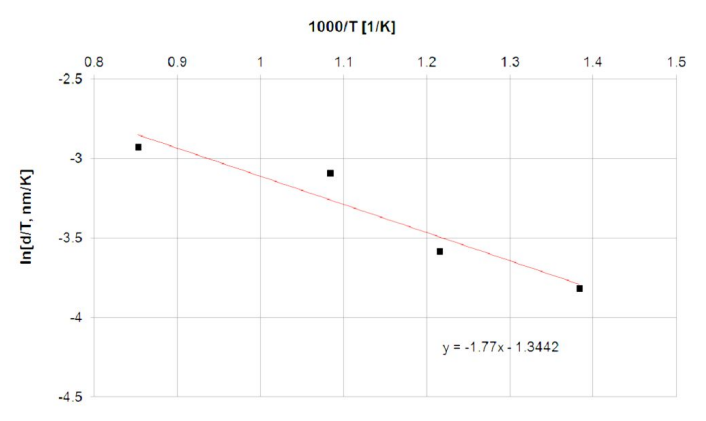

Fig. 7. Eyring plot of nanocomposite $\mathrm{SiO}_{2}$ film.

collected in a spectral range of $300 \mathrm{~nm}$ to $1000 \mathrm{~nm}$ at a $30^{\circ}$ angle of incidence with s and p-polarization modes, respectively. When the annealing temperature of the nanocomposite $\mathrm{SiO}_{2}$ film was increased, the transmittance of the film decreased for both $\mathrm{s}$ and $\mathrm{p}$ polarization modes. This can be attributed to increasing of the average particle size due to Ostwald ripening of small particles. A decrease of fundamental absorption was seen at shorter wavelengths $(\lambda<320 \mathrm{~nm})$. At $550 \mathrm{~nm}$ wavelength, the transmittance of the nanocomposite $\mathrm{SiO}_{2}$ films changed from $69.2 \%$ to $86.7 \%$ in the s-polarization mode and from $78.1 \%$ to $90.2 \%$ in the p-polarization mode with a decrease of annealing temperature from $1100{ }^{\circ} \mathrm{C}$ to $450{ }^{\circ} \mathrm{C}$. 
The higher transmittance observed at $450{ }^{\circ} \mathrm{C}$ is attributed to structural homogeneity, less scattering and absorption effects as is clearly observed in Fig. 8 and Fig. 9 at longer wavelengths $(\lambda>$ $320 \mathrm{~nm})$.

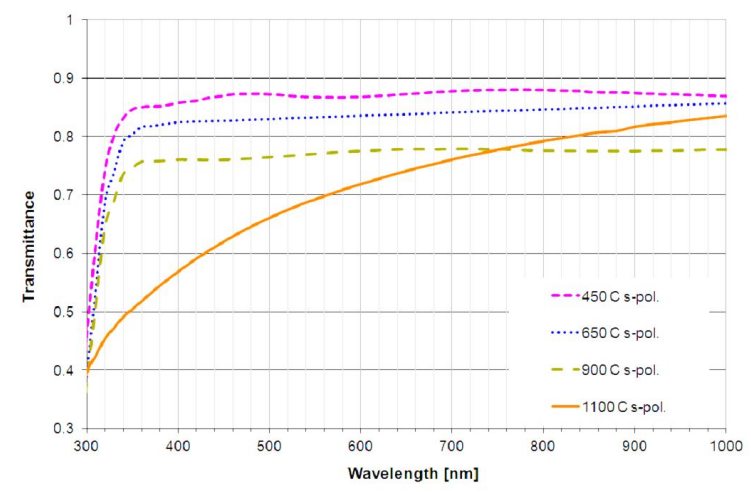

Fig. 8. Transmittance data in the s-polarization mode of nanocomposite $\mathrm{SiO}_{2}$ film annealed at different heat treatment temperatures.

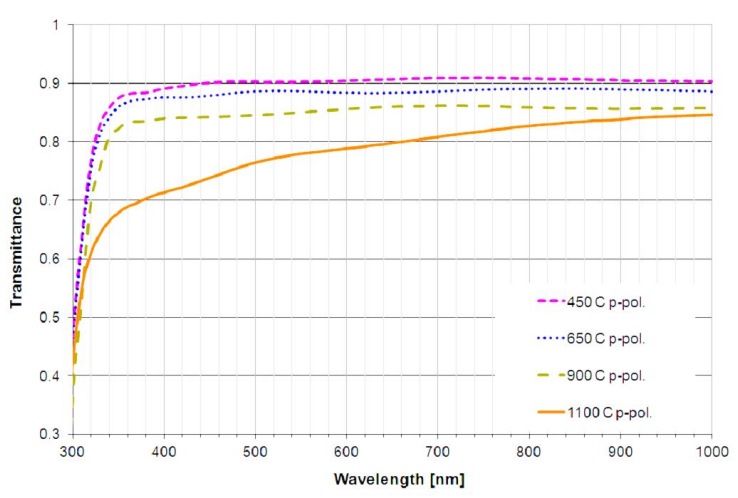

Fig. 9. Transmittance data in the p-polarization mode of nanocomposite $\mathrm{SiO}_{2}$ film annealed at different heat treatment temperatures.

Fig. 10 and Fig. 11 present refractive indices and extinction coefficients of the films which were evaluated using the Pro-Optix software of the NKD analyzer. When the annealing temperature was increased, the refractive index of the nanocomposite $\mathrm{SiO}_{2}$ films increased from 1.56 to 1.59 at $550 \mathrm{~nm}$ due to densification of the films. In Fig. 11, the extinction coefficients of the nanocomposite $\mathrm{SiO}_{2}$ films at different temperatures exhibit similar behavior. For example, the nanocomposite $\mathrm{SiO}_{2}$ films

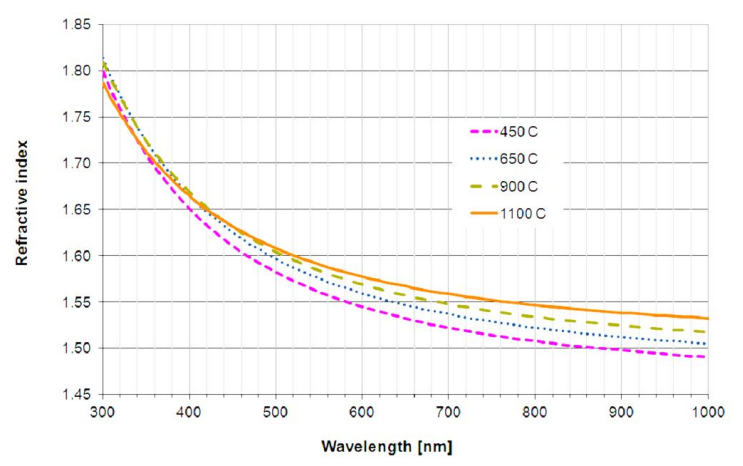

Fig. 10. Refractive index of nanocomposite $\mathrm{SiO}_{2}$ films annealed at different heat treatment temperatures.

all have an extinction coefficient value of 0.17 at $300 \mathrm{~nm}$ wavelength, and the extinction coefficients of the films decreases with the wavelength. Extinction coefficient values reach the minima for all annealing temperatures in the $350 \mathrm{~nm}$ to $360 \mathrm{~nm}$ wavelength range, and then they increase with the increase of the annealing temperature from $450{ }^{\circ} \mathrm{C}$ to $1100{ }^{\circ} \mathrm{C}$, at longer wavelengths. For the annealing temperature of $1100{ }^{\circ} \mathrm{C}$, the extinction coefficient decreases after $850 \mathrm{~nm}$ wavelength. Finally, the extinction coefficients of the nanocomposite $\mathrm{SiO}_{2}$ films with other annealing temperatures reach the maximum values, and then decrease with the wavelength. The inset of Fig. 11 shows the extrapolation of the extinction coefficient value where it increases in the region of $295 \mathrm{~nm}$ to $303 \mathrm{~nm}$ wavelengths. For further investigations, Fig. 12 indicates the UV-Vis absorbance spectra of the nanocomposite $\mathrm{SiO}_{2}$ films. The absorption edge of the nanocomposite $\mathrm{SiO}_{2}$ films shifted to shorter wavelengths with a decreasing particle size due to a quantum confinement effect, in the wavelength region of $295 \mathrm{~nm}$ to $303 \mathrm{~nm}$. The particle sizes increased with an increase in annealing temperature from $450{ }^{\circ} \mathrm{C}$ to $900{ }^{\circ} \mathrm{C}$. At $1100{ }^{\circ} \mathrm{C}$, the particle size decreased due to the crystallization of the nanoparticled film. Both UV-Vis absorbance spectra and calculated extinction coefficients of these films confirm the change of the particle size with the annealing temperature. 


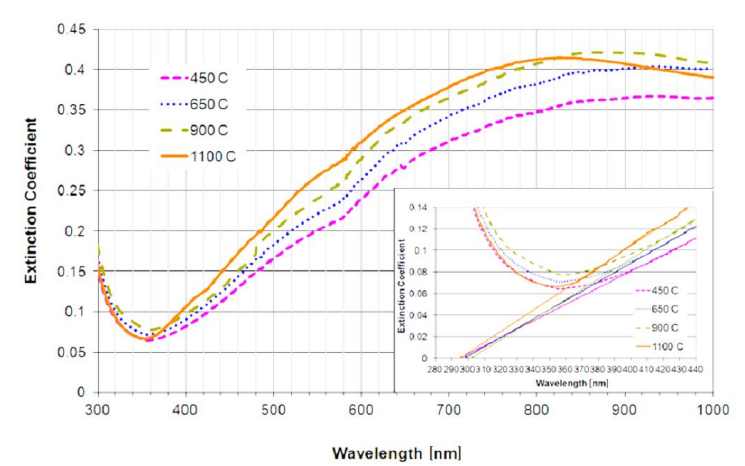

Fig. 11. Extinction coefficient of nanocomposite $\mathrm{SiO}_{2}$ films annealed at different heat treatment temperatures.

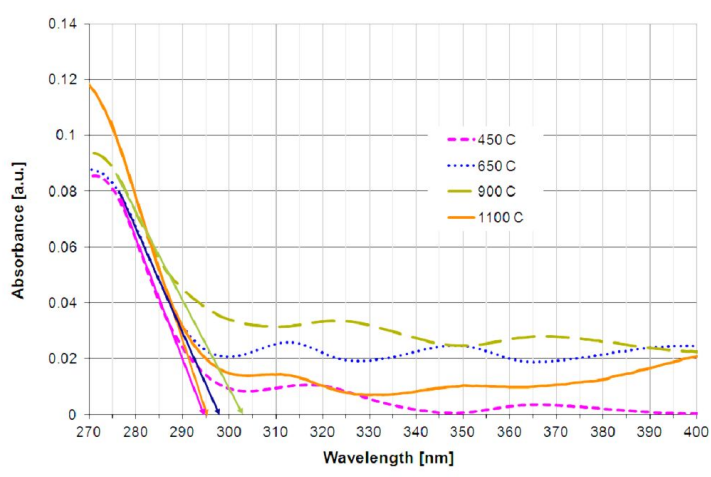

Fig. 12. Extrapolation of the UV-Vis absorbance spectra of nanocomposite $\mathrm{SiO}_{2}$ films heat-treated at different annealing temperatures.

\section{Conclusions}

Nanocomposite $\mathrm{SiO}_{2}$ thin films were synthesized, and their particle size was controlled with the heat treatment process after the formation of the films. In the nanocomposite $\mathrm{SiO}_{2}$ films, $\mathrm{SiO}_{2}$ nanoparticles were distributed almost uniformly in the thin film matrix at annealing temperatures of $450{ }^{\circ} \mathrm{C}, 650{ }^{\circ} \mathrm{C}, 900{ }^{\circ} \mathrm{C}$ and $1100{ }^{\circ} \mathrm{C}$ which was confirmed by AFM and SEM measurements. The particle sizes increased gradually with an increase in annealing temperature from $450{ }^{\circ} \mathrm{C}$ to $900{ }^{\circ} \mathrm{C}$. This was caused by the heat-induced expansion of the particle size Ostwald ripening- and agglomeration of small particles. At $1100{ }^{\circ} \mathrm{C}$, the particle size decreased due to the phase transformation of the nano- $\mathrm{SiO}_{2}$ thin film from an amorphous phase to the $\alpha$-cristobalite one. Also, the growth of silica nanoparticles was prevented by the nanoparticled composite structure. Nanocomposite $\mathrm{SiO}_{2}$ film had the nanoparticles with a size of $16 \mathrm{~nm}$ whereas the particle size of nano- $\mathrm{SiO}_{2}$ was $50 \mathrm{~nm}$ as the composite nanoparticles were encapsulated. Both sizes were measured for the ratio of ammonia/TEOS $=1: 32$ at the same annealing temperature of $450{ }^{\circ} \mathrm{C}$. The calculated crystallite size of the nano-SiO 2 thin film was also in agreement with the SEM measurements for the annealing temperature of $1100{ }^{\circ} \mathrm{C}$.

The optical studies revealed that the transmittance of the films decreased with the annealing temperature. The refractive index and the extinction coefficient of the nanocomposite $\mathrm{SiO}_{2}$ films increased with the temperature as increasing temperature caused an increase of packing density of the film (tighter packing of particles). The absorption edge of the nanocomposite $\mathrm{SiO}_{2}$ films shifted to shorter wavelengths with a decrease in the heat treatment temperature in the range of $900{ }^{\circ} \mathrm{C}$ to $450{ }^{\circ} \mathrm{C}$. The quantum confinement effect of the nanoparticles was confirmed by the cutoff wavelength shift. Both UV-Vis spectrometer and NKD-analyzer measurements confirmed the cut-off wavelength shift in the absorbance spectra and extinction coefficient graphs of the nanocomposite $\mathrm{SiO}_{2}$ silica films. The activation energy and enthalpy were calculated as $22.3 \mathrm{~kJ} / \mathrm{mol}$ and $14.7 \mathrm{~kJ} / \mathrm{mol}$, respectively. The calculated activation energy is much lower in comparison to the values reported in the literature but there is no comparable study that determines the activation enthalpy of the nanoparticled composite films containing silica nanoparticles.

In solar cells and optical filter applications, controlling the band gap energy - or cut-off wavelength - and the refractive index of the films is extremely important. This study indicates that it is possible to alter optical properties of nanocomposite $\mathrm{SiO}_{2}$ thin films with different particle sizes.

\section{Acknowledgements}

The Research Fund of Istanbul Technical University (BAP Project No.: 34231) has generously supported this research. 


\section{References}

[1] Vogel R., Surawski P.P.T., Littleton B.N., Miller C.R., LAWrie G.A., BATtersby B.J., TRAU M., J. Colloid. Interf. Sci., 310 (2007), 144.

[2] Gurav J. L., Nadargi D. Y., Rao A. V., Appl. Surf. Sci., 255 (2008), 3019.

[3] Saygin Hinczewsi D., Hinczewski M., TepeHan F.Z., Tepehan G.G., Sol. Energ. Mat. Sol. C., 87 (2005), 181.

[4] Schuler A., DutTa D., Chambrier E., Roecker C., Temmerman G., Oelhafen P., SCARTEZZini J.-L., Sol. Energ. Mat. Sol. C., 90 (2006), 2894.

[5] Dubey R. S., Rajesh Y. B. R. D., More M. A., Mater. Today-Proc., 2 (2015), 3575.

[6] Vasiliu I., Gartner M., Anastasescu M., ToDAN L., Predoană L., Elişa M., Negrilă C., UNgureanu F., Logofătu C., Moldovan A., BîrJEGA R., ZAHARESCU M., Thin Solid Films, 515, 16 (2007), 6601.

[7] Predoana L., Preda S., Anastasescu M., Stoica M., Voicescu M., Munteanu C., Tomescu R., Cristea D., Opt. Mater., 46 (2015), 481.

[8] ISlam S., Bidin N., Riaz S., NASEEM S., MARSiN F.M., Sensor Actuat. B-Chem., 225 (2016), 66.

[9] AkKaya ArIer Ü. Ö., Optik, 127 (2016), 6439.

[10] Ali A. M., Harraz F. A., Ismail A. A., Al-S AYari S.A., Algarni H., Al-Sehemi A. G., Thin Solid Films, 605 (2016), 277.

[11] TABatabaei S., Shukohfar A., Aghababazadeh R., Mirhabibi A., J. Phys., 26 (2006), 371.

[12] Wang C.T., Wu C.L., Chen I.C., Huang Y.H., Sensor Actuat. B-Chem., 107 (2005), 402.

[13] Stöber W., Fink A., Bohn E., J. Colloid. Interf. Sci., 26 (1968), 62.

[14] Huang Y., Pemberton J. E., Colloid. Surface. A, 377 (2011), 76.

[15] Jung I.K., GuraV J. L., Ha T.J, Choi S.G., BAEK S., PARK H.H., Ceram. Int., 38 (2012), 105.

[16] Bredereck K., Effenberger F., Tretter M., J. Colloid. Interf. Sci., 360 (2011), 408.

[17] Costa C.A.R., Valadares L.F., Galembeck F., Colloid. Surface. A, 302 (2007), 371.

[18] Xu G.Q., Zheng Z.X., TAng W.M., Wu Y.C., J. Lumin., 126 (2007), 43.

[19] Rahman I.A., Vejayakumaran P., Sipaut C.S., Ismail J., CheE C.K., Ceram. Int., 34 (2008), 2059.

[20] Kim J. M., Chang S. M., Kong S. M., KIM K.S., KIM J., KIM W.S., Ceram. Int., 35 (2009), 1015.

[21] BAE G.Y., Min B.G., JeOng Y.G., LeE S.C., JANG J.H., Koo G.H., J. Colloid. Interf. Sci., 337 (2009), 170.

[22] Anastasescu C., Anastasescu M., Teodorescu V.S., Gartner M., Zaharescu M., J. Non-Cryst. Solids, 356 (2010), 2634.
[23] Wang X.D., Shen Z.X., Sang T., Cheng X.B., Li M., FChen L.Y., WANG Z.S., J. Colloid. Interf. Sci., 341 (2010), 23.

[24] Park S. K., Kim K. D., Kim H. T., Colloid. Surface. A, 197 (2002), 7.

[25] Marini M., Pourabbas B., Pilati F., Fabbri P., Colloid. Surface. A, 317 (2008), 473.

[26] Morales-SaAvedra O. G., Zanella R., Mater. Chem. Phys., 124 (2010), 816.

[27] Blute I., Pugh R. J., Pas J. V., Callaghan I., Colloid. Surface. A, 337 (2009), 127.

[28] Du H., Hamilton P. D., Reilly M. A., D’Avignon A., Biswas P., Ravi N., J. Colloid. Interf. Sci., 340 (2009), 202.

[29] Haranath D., Gandhi N., Sahai S., Shanker M. H. V., Chem. Phys. Lett., 496 (2010), 100.

[30] Shena J., Wanga J., Zhoua B., Denga Z., Wenga Z., Zhub L., Zhaов L., Lib Y., J. Non-Cryst. Solids, 225 (1998), 315.

[31] Saygin Hinczewski D., Hinczewski M., Sorar İ., Tepehan F.Z., Tepehan G.G., Sol. Energ. Mat. Sol. C., 92 (2008), 821.

[32] Koc K., Tepehan F.Z., Tepehan G.G., J. Mater. Sci., 40 (2005), 1363

[33] Sorar I., SAYGIN-HinCZEWSKI D., HincZewsi M., Tepehan F.Z., Appl. Surf. Sci., 257 (2011), 7343.

[34] ÖzuĞur Uysal B., Tepehan F. Z., J. Sol-Gel Sci. Techn., 63 (2012), 177.

[35] BATtisha I.K., AFIFy H.H., BADR Y., J. Sol-Gel Sci. Techn., 25 (2002), 5.

[36] Li X., Yin X., Zhang L., He S., J. Non-Cryst. Solids, 354 (2008), 3254.

[37] Dutta S.K., Spriggs R.M., J. Am. Ceram. Soc., 53 (1970), 61.

[38] Dey D., Bradt R.C., J. Am. Ceram. Soc., 75 (1992), 2529.

[39] Zhang T.S., MA J., Kong L.B., ZENG Z.Q., Hing P., Kilner J.A., Mat. Sci. Eng. B-Adv., 103 (2003), 177.

[40] Glasstone S., LAidler K.J., Eyring H., The Theory Of Rate Processes, McGraw-Hill, New York, 1941.

[41] Flesch J., Kerner D., Riemenschneider H., Reimert R., Powder Technol., 183 (2008), 467.

[42] Rimer J.D., Vlachos D.G., Lobo R.F., The $40^{\text {th }}$ Anniversary of International Zeolite Conference, (2007), 133.

[43] Chen Z.-L., Shen P., Ceram. Int., 39 (2013), 2365.

[44] Shiue Y.S., Matthewson M.J., J. Eur. Ceram. Soc., 22 (2002), 2325.

[45] Fertani-Gmati M., Brahim K., Khattech I., JeMAL M., Thermochim. Acta, 594 (2014), 58.

Received 2017-02-16 Accepted 2018-12-29 